Науковий вісник Львівського національного університету ветеринарної медицини та біотехнологій імені С.З. Гжицького

Scientific Messenger of Lviv National University of Veterinary Medicine and Biotechnologies

doi:10.15421/nvlvet8120

ISSN 2519-2701 print

ISSN 2518-1327 online

$\underline{\text { http://nvlvet.com.ua/ }}$

УДК 338.48(477)

\title{
Перспективи розвитку аграрного туризму в Карпатському регіоні
}

О.Я. Гримак, М.В. Вовк, В.Я. Джура

grumo@i.ua, mirkavovk21@gmail.com

Львівський національний університет ветеринарної медицини та біотехнологій імені С.3. Гжицького, вул. Пекарська, 50, Львів, 79010, Україна

На сьогоднішній день діяльність агротуристичних підприємств є важливим елементом дослідження соиіальноекономічних відносин на місиевому, регіональному та національному рівнях. Агротуризм став альтернативною формою ефективного функиіонування та диверсифікаиії фермерських господарств. Розвиток даної форми підприємництва може відіграти вирішальну роль у відродженні економіки сільських територій в Карпатському регіоні, де перспективи агротуристичної індустрії були і залишаються одними з найкращих в Украйні. Використання агротуристичного потенціалу в сучасних умовах децентралізачії управління призведе до сочіально-економічного розвитку регіону за рахунок збільшення дохідної частини місцевих бюджетів, підвищення інвестиційної привабливості, збільшення зайнятості населення, особливо у сільських здебільшого депресивних районах, збереженню ландиафту чи його позитивній зміні, раціональному використанню природної та культурно-історичної спадщзини.

Ключові слова: підприємство, економіка, розвиток, потенціал, стратегія розвитку, агротуризм, зелений туризм, агротуристична індустрія, сільська територія, сільське населення, Карпатський регіон.

\section{Перспективы развития аграрного туризма в Карпатском регионе}

\author{
О.Я. Грымак, М.В. Вовк, В.Я. Джура \\ grumo@i.ua,mirkavovk21@gmail.com
}

Львовский национальный университет ветеринарной медицины и биотехнологий имени С.3. Гюицкого, ул. Пекарская, 50, г. Львов, 79010, Украина

\begin{abstract}
На сегодняшний день деятельность агротуристических предприятий является важным элементом исследования соииально-экономических отношений на местном, региональном и национальном уровнях. Агротуризм стал альтернативной формой эффективного функиионирования и диверсификаичи фермерских хозяйств. Развитие данной формы предпринимательства может сыграть решаюшую роль в возрождении экономики сельских территорий в Карпатском регионе, где перспективы агротуристической индустрии были и остаются одними из лучших в Украине. Использование агротуристического потенциала в современных условиях децентрализации управления приведет к социально-экономическому развитию региона за счет увеличения доходной части местных бюджетов, повышение инвестиционной привлекательности, увеличение занятости населения, особенно в сельских основном депрессивных районах, сохранению ландмафта или его позитивном изменении, рачиональному использованию природного и культурно-исторического наследия.

Ключевые слова: предприятие, экономика, развитие, потенциал, стратегия развития, агротуризм, зеленый туризм, агротуристична индустрия, сельская территория, сельское население, Карпатский регион.
\end{abstract}

\section{Prospects for the development of agrarian tourism in the Carpathian region}

\author{
O. Hrymak, M. Vovk, V. Jura \\ grumo@i.ua,mirkavovk21@gmail.com
}

\section{Citation:}

Hrymak, O., Vovk, M., Jura, V. (2017). Prospects for the development of agrarian tourism in the Carpathian region. Scientific Messenger LNUVMB, 19(81), 114-117. 


\section{Stepan Gzhytskyi National University of Veterinary Medicine and Biotechnologies Lviv,} Pekarska Str., 50, Lviv, 79010, Ukraine

To date, the activities of agritourism enterprises is an important element in the study of socio-economic relations at local, regional and national levels. Agritourism has become an alternative form of effective functioning and on-farm diversification. The development of this form of entrepreneurship can play a crucial role in the revival of the economy of rural areas in the Carpathian region, where the prospects, the tourism industry was and still is one of the best in Ukraine. The use of agro-tourist potential in the modern conditions of decentralization of management will lead to socio-economic development of the region by increasing revenues of local budgets, increase of investment attractiveness, increase of employment, especially in rural mostly rural areas, landscape conservation or positive change, rational use of natural and cultural-historical heritage. Agrarian tourism is a real alternative for today's unemployment and mass migration of the rural population. This kind of entrepreneurial activity can create a new labor market, become a source of income for the rural dweller and increase the general standard of living in the village.

The purpose of this article is to present the specifics of agrarian tourism as a form of entrepreneurial activity in the village in the Carpathian region. The paper deals with the actual issues of research of the specificity of agro-tourism, the principles of its development, the introduction of tourism services in rural areas with a view to diversifying socio-economic activity, raising the level of well-being and prestige of rural labor. To achieve the goal, many years of research experience in this field were analyzed, abstractlogical and statistical methods of analysis and cognition were used.

Keywords: enterprise, economics, development potential, development strategy, agri-tourism, green tourism, agroturistica industry, rural territory, rural population, Carpathian region.

\section{Вступ}

Зелений сільський туризм як форма підприємницької діяльності на теренах нашої держави почав розвиватись доволі недавно. В Радянському Союзі він сприймався лише крізь призму соціальних відносин, економічні аспекти даного виду господарювання не враховувались. Соціально-політичні зміни, які відбулися, посприяли розвитку туризму як окремої сфери діяльності. Сьогодні агротуризм, як специфічна форма підприємницької діяльності, став одним із пріоритетних напрямів розвитку сільських територій.

Аграрний туризм - це реальна альтернативна сьогоднішньому безробіттю та масовій міграції сільського населення. Даний вид підприємницької діяльності може створити новий ринок праці, стати джерелом доходу для сільського мешканця та підвищити загальний рівень життя на селі.

Україна має сприятливі умови для розвитку сільського зеленого туризму, який найуспішніше можна розвивати у регіонах з низьким рівнем індустріалізації та урбанізації. До них можна віднести і Карпатський регіон, який характеризується великою часткою сільського населення, слабким розвитком сільського господарства, високим рівнем безробіття, низьким рівнем доходу населення, проте сприятливими природними i ландшафтними умовами, культурноісторичною спадщиною, що в значній мірі може привернути увагу потенційного туриста.

\section{Матеріал і методи досліджень}

Метою цієї статті є представлення специфіки аграрного туризму як форми підприємницької діяльності на селі в Карпатському регіоні. У роботі розглядаються актуальні питання дослідження специфіки аграрного туризму, засад його розвитку, впровадження туристичних послуг в сільській місцевості з метою диверсифікації соціально-економічної діяльності, підвищення рівня добробуту та престижу сільської праці. Щоб досягнути поставленої мети, було проаналізовано багаторічний досвід досліджень у цій сфері, вико- ристано абстрактно-логічний та статистичний методи аналізу та пізнання.

\section{Результати та їх обговорення}

Поняття «аграрний туризм», «сільський туризм» в українській літературі з'явився в кінці XX століття. Він був сформований шляхом поєднання таких елементів як агропромисловий комплекс та туризм. Незважаючи на те, що існують певні розбіжності в розумінні таких понять як «агротуризм», «зелений туризм», «сільський туризм», найширше їх можна трактувати як туризм, що базується в сільських будинках (дворах) або фермах, або загалом у сільській місцевості, але не включає відпочинок на особливих рекреаційних територіях - таких як національні парки, лісові зони і т. д. Простіше кажучи, це майже всі форми відпочинку, що можливі в сільській місцевості (Yemets and Landel, 1992).

Щодо правового статусу, то на даний час нормативною базою $є$ Закон України «Про туризм» від 18.11.2003 p. №1282-IV та «Про с особисте селянське господарство» від 15.05.2003 р. №742- IV, Постанова Кабінету Міністрів України від 15.03.2006 р. №297 «Порядок надання послуг 3 тимчасового розміщення (проживання)». В проекті Законі України «Про сільський зелений туризм» дана форма підприємництва трактується як «відпочинковий вид туризму, що перевчає тимчасове перебування туристів у сільській місцевості (селі) та отримання ними послуг сільського зеленого туризму. Послуги сільського зеленого туризму - діяльність членів особистого селянського, особистого підсобного або фермерського господарства 3 надання послуг бронювання, розміщення, харчування, інформаційного обслуговування, інших видів послуг, що спрямовані на задоволення потреб туристів» (Draft Law on Rural and Rural Green Tourism).

Для визначення специфіки агротуризму, ми виділили чотири основні групи чинників, що впливають на його розвиток:

1. Туристичний потенціал сільської території: природно-кліматичні умови, культурно-історична 
спадщина, соціальна, економічна та туристична інфраструктура;

2. Розважально-атракційна привабливість сільської території: організація дозвілля, напрямки подорожей, набір конкретних товарів та туристичних послуг.

3. Зовнішні зв'язки та інтеграційні процеси усередині: інвестиційно-інноваційна діяльність, технічний прогрес, екологічна безпека та якість навколишнього середовища.

4. Загальні умови стану та розвитку сільського господарства в даному регіоні: структура і розмір сільськогосподарських підприємств, форми господарювання, умови користування природними ресурсами.

Bci ці чинники впливають на туристичний потенціал території, а отже і на привабливість самого агротуристичного господарства.

Що стосується розвитку Карпатського регіону, то варто відмітити, що за останній час посилились міграційні процеси населення, особливо на міжрегіональному і міждержавному рівнях. Міграція, як правило, йде в сусідні європейські країни. Це негативно впливає на розвиток власної економіки, але, водночас, сприяє припливу валютних ресурсів, які в основному спрямовуються на соціальний розвиток. Це також сприяє створенню нових малих підприємств, розширенню виробництва та зменшенню безробіття працездатного населення.

Карпатський регіон відноситься до слабо розвинених: ВВП на душу населення складає - 20289 грн. в рік, що на 40\% менше, ніж в середньому по Україні; рівень заробітної плати приблизно вдвічі менший, від аналогічного показника по Україні; спостерігається низька зайнятість населення. Незадовільним $є$ також стан технічної інфраструктури, соціальні та економічні умови, а також низький рівень життя населення. На підставі можливих умов і факторів росту можна запропонувати три основні галузі розвитку даного регіону: промислову, сільськогосподарську та рекреаційно-туристичну.

Варто відмітити, що Карпатський регіон є досить неоднорідним, адже до його складу входять гірські, передгірські і низинні території. I найнижчі показники діяльності спостерігаються саме в гірських і передгірських районах. Проте даний регіон має об'єктивні і вагомі передумови для його розвитку: природнокліматичний потенціал, мальовничі ландшафти, чисте повітря, цілющі мінеральні води, привабливі туристичні маршрути, збережені національні традиції і фольклор, архітектурні пам'ятки, рекреаційні можливості. Тому враховуючи географічну специфіку та природно-кліматичні умови, альтернативою розвитку гірських і передгірських районів є рекреаційно-туристична галузь.

Сучасні тенденції розвитку туризму вимагають формування та просування туристичного продукту, скерованого на конкретного споживача, який сьогодні $\epsilon$ більш інформований, незалежний, розкутий, критично й вибагливо відноситься до пропонованих йому товарів і послуг (Decision of the regional council). Формування туристичного продукту у відповідності до потреб споживача потребує запровадження ефективної системи маркетингу та просування. Тому щодо розважально-атракційної складової розвитку агротуризму, то досліджуваний регіон має усі підстави для їі розвитку. Крім відомих форм відпочинку, таких як рибальство, збирання грибів та ягід, верхової їзди, які можна запропонувати і в інших регіонах, Карпатський регіон має свої специфічні відмінності. Тут можна запропонувати такі види туристичних розваг, які завдяки збереженим традиціям, немає в інших регіонах. Адже специфіка вирощування і випасу овець залишається однією з небагатьох областей діяльності людини, яка протягом багатьох років, не дивлячись на науково-технічний прогрес у всьому світі, практично не змінилися. Даний вид сільського господарства може привабити як вітчизняних так і іноземних туристів. I це може стати ще одним джерелом доходів сільських жителів, адже сьогодні спостерігається підвищений інтерес до цієї форми дозвілля. Також існує велика кількість турів, які пропонують саме такий вид активного відпочинку, як фітотерапія, апітерапія і здорове харчування, що складається 3 продуктів, які надходять 3 даних ферм.

Також однією 3 найбільш важливих чинників в агротуристстичному бізнесі $є$ екологічна складова. Сучасні економічні виклики призводять до прагнення забезпечити найбільш ефективні та органічні методи ведення сільськогосподарського виробництва, та пошуку альтернативних шляхів використання їх продукції. Тому необхідною умовою є дотримання концепції сталого розвитку, адже існує проблема забруднення навколишнього середовища, в тому числі і за рахунок ведення інтенсивного тваринництва. Саме органічне сільське господарство $є$ найбільш інвестиційно привабливим аграрній сфері.

Незважаючи на активну діяльність населення Карпатського регіону у сільському господарстві, рівень і темпи його розвитку, ефективність виробництва та якість продукції не є задовільними. У загальних обсягах валової продукції сільського господарства України частка Карпатського регіону є незначною. Зважаючи на значну частку сільського населення Карпатського регіону, реальний рівень виробництва сільськогосподарської продукції $є$ вкрай низьким і свідчить про невикористання наявного земельного та людського потенціалу регіону (Krupin, 2012).

Тому з метою активізації туристичної діяльності необхідно пропагувати туристичні можливості регіону шляхом запозичення іноземного досвіду, всебічного обміну між учасниками туристичної діяльності, розвитку різноманітних видів аграрного туризму, реалізація конкурентних туристичних переваг регіону шляхом забезпечення інвестиційно-інноваційної діяльності.

\section{Висновки}

Аграрний туризм як одна із форм несільськогосподарської діяльності сільського населення дозволяє забезпечити стійкий розвиток сільських територій. Важливим результатом $є$ розширення можливостей реалізації продукції особистого господарства, диверсифікація сільськогосподарського виробництва, зменшення міграційних процесів за рахунок підвищення 
зайнятості та доходності сільських жителів, забезпечення добробуту та збереження національних традицій.

Динамічний розвиток сільського зеленого туризму має стати частиною багатофункціонального розвитку сільських територій, в тому числі Карпатського регіону. Це в свою чергу принесе як соціальний так і економічний ефект, адже стане не тільки важливим джерелом доходу для сільських жителів, але і дасть можливість розвинути їх підприємницький хист. Для цього необхідно створити сприятливе середовище для розвитку даного виду підприємницької діяльності 3 позиції співпраці як з боку державних органів влади, так і місцевих сільських громад. Адже тільки бажання працювати і відкриття нових перспектив і можливостей підприємницької діяльності на селі це основні фактори розвитку аграрного туризму.

\section{Бібліографічні посилання}

Yemets, G.S., Landel, M.A. (1992). Regional approach to the management of economic processes: a monograph. $\mathrm{K}$ : View «Naukova Dumka» (in Ukrainian).

Draft Law on Rural and Rural Green Tourism. Mode of access: rada.gov.ua/pls/zweb2/webproc4_2?pf3516 $=4299 \& \mathrm{skl}=5$ (in Ukrainian).

Decision of the regional council dated 17.10.2014 № 1401-32 / 2014 «On the Strategy for the Development of Ivano-Frankivsk Oblast for the Period until 2020». Mode of access: http://www.if.gov.ua/page/19310 (in Ukrainian).

Krupin, V.Y. (2012). Economic Development of Rural Areas of the Carpathian Region of Ukraine: State, Trends, Prospects. Regional Economics. 1, 55 (in Ukrainian). 